JOTE Volume 2 Nomor 1 Tahun 2020 Halaman 146-155 JOURNAL ON TEACHER EDUCATION

Research \& Learning in Faculty of Education

\title{
MENANAMKAN MORAL SEJAK DINI MELALUI BUKU BERGAMBAR PILAR KARAKTER SOPAN SANTUN PADA ANAK USIA DINI DI DESA GERBANG SARI, KECAMATAN TAPUNG HILIR KABUPATEN KAMPAR
}

\author{
Minarni Purba', Syahrial ${ }^{2}$, Moh. Fauziddin ${ }^{3}$ \\ Program Studi Pendidikan Guru Pendidikan Anak Usia Dini, \\ Fakultas IImu Pendidikan, Universitas Pahlawan Tuanku Tambusai \\ Email : minarni purba090@com
}

\begin{abstract}
Abstrak
Tujuan penelitian secara umum adalah mendeskripsikan penanaman moral anak usia dini di KB Kartini Beringin Lestari. Metode penelitian adalah menggunakan PTK yang dilakukan dua siklus. Subjek penelitian adalah anak KB Kartini Beringin Lestari berjumlah 20 anak didik. Alat pengumpulan data yaitu dengan menggunakan lembar observasi kegiatan anak dan guru. Tekhnik analisa data yaitu tekhnik statistik deskriptif. Hasil penelitian menunjukkan bahwa: nilai karaktek sopan santun dapat meningkatkan melalui metode bercerita dengan media buku bergambar pilar karakter sopan santun. Hasil penelitian tindakan kelas yang semula pada pra siklus persentase anak dengan kriteria sangat baik $31,87 \%$ meningkat menjadi $58,43 \%$ setelah di adakan penelitian tindakan kelas pada siklus 1. Lalu penelitian melakukan penelitian kembali pada pertemuan I sampai III untuk siklus II, kemampuan moral untuk karaktek sopan santun anak meningkat signifikan menjadi $88,75 \%$. Kesimpulannya adalah dengan buku bergambar pilar karakter sopan santun, kemampuan moral anak KB Kartini meningkat dengan baik.
\end{abstract}

Kata kunci: Moral, buku bergambar pilar, karakter sopan santun.

\section{Abstract}

The research objective in general is to describe the moral cultivation of early childhood in KB Kartini Beringin Lestari. The research method is to use PTK which is carried out in two cycles. The research subjects were 20 children of KB Kartini Beringin Lestari. The data collection tool is by using the child and teacher activity observation sheet. Data analysis techniques are descriptive statistical techniques. The results showed that: the character value of courtesy can improve through the method of telling stories with pictorial books as the pillars of polite characters. The results of the classroom action research, which was originally in the pre-cycle, the percentage of children with excellent criteria was $31.87 \%$, increased to $58.43 \%$ after classroom action research was held in cycle 1 . Then the research conducted the research again at meetings I to III for cycle II, Moral for the polite character of children increased significantly to $88.75 \%$. The conclusion is that with a picture book about the pillars of courtesy, the moral abilities of KB Kartini's children improve well.

Keywords: Moral, picture books of pillars, character of manners. 


\section{PENDAHULUAN}

Pendidikan karakter yang berkualitas perlu di bentuk dan dibina sejak usia dini. usia dini merupakan masa keritis bagi pembentukan karakter seseorang. Banyak pakar mengatakan bahwa kegagalan penanaman karakter pada seseorang sejak usia dini, akan membentuk pribadi yang bermasalah di masa dewasanya kelak. Selain itu, menanamkan moral kepada generasi muda adalah usaha yang strategis. Ada sebuah pepatah yang mengemukakan oleh Thomas Lickona: "Walaupun jumlah anak-anak hanya 25\% dari total jumlah penduduk, tetapi menntukan $100 \%$ masa depan". Oleh karena itu penanaman moral melalui pendidkan karakter sedini mungkin kepada anak didik adalah kunci utama untuk membangun bangsa. Pendidikan karakter sebagai salah satu alternatif pendidikan hendaknya dapat dilaksanakan di mulai dari keluarga. Kelompok Bermain pendidikan dasar, menengah, pendidikan tinggi.

Dari kajian beberapa buku penulis mencoba menguraikan istilah karakter sebagai berikut: istilah karakter baru di pakai secara khusus dalam konteks pendidikan pendekatan analis - spritulis dalam pendidikan, yang juga dikenal dengan teori pendidikan normatif. Lahirnya pendidikan karakter merupakan usaha untuk menghubungkan kembali pedagogik ideal spritual yang sempat di terjang gelombang positivisme yang di pelopori oleh filosof perancis Aguste Combre. Kata karakter berasal dari kata yunani, Charassein, yang berarti mengukir sehingga terbentuk sebuah pola. Mempunyai akhlak-akhlak mulia adalah tidak secara otomatis dimiliki oleh setiap manusia begitu ia dilahirkan, tetapi memerlukan proses panjang melalui pengasuhan dan pendidikan(proses pengukiran). Dalam istilah bahasa arab karaktek mirip dengan akhlak(akar atau khuluk), yaitu tabiat atau kebiasaan melakukan hal yang baik. Alghazali menggambarkan bahwa akhlak adalah tingkah laku seseorang yang berasal dari hati yang baik. Oleh karena itu pendidikan karakter adalah usaha aktif untuk membentuk kebiasaan baik (habit), sehingga sifat anak sudah terukir sejak kecil. Allah menurunkan petunjuk melalui para nabi dan rasulnya untuk manusia agar senantiasa berprilaku sesuai dengan yang diinginkan Allah oleh wakil Allah di muka bumi. Oleh karena itu pendidikan karakter merupakan keseluruhan dinamika nasional antar pribadi dengan berbagai macam dimensi baik dari dalam maupun dari luar. Agar pribadi itu semakin menghayati kebiasaannya sehingga ia dapat semakin bertanggung jawab atas pertumbuhan diri sendiri sebagai pribadi dan perkembangan orang lain dalam hidup mereka secara singkat. Pendidikan karakter diartikan sebagai bantuan sosial individu itu dapat dengan cara menghayati kebebasannya ketika hidup bersama dengan orang lain dalam dunia. Di dalam qudsi juga digambarkan bahwa manusia 
dilahirkan dalam keadaan fitrah(suci), seperti yang diriwayatkan muslim, telah berfirman Allah SWT "Sesungguhnya Aku telah menciptakan hamba-hamba $\mathrm{Ku}$ dalam keadaan lurus, suci dan bersih kemudian datanglah syaitan-syaitan yang menggelincirkan mereka dan manyesatkannya dari kebenaran mereka dan syaitan-syaitan pun telah mengharamkan segala sesuatu bagi mereka apa-apa yang telah dihalalkan".

Pendidikan karakter memiliki makna lebih tinggi dari pendidikan moral, karena pendidikan karakter itu hanya berkaitan dengan masalah benar salah, tetapi bagaimana menanamkan kebiasaan (habit) tentang hal-hal yang baik dalam kehidupan, sehingga anak peserta didik/memiliki kesadaran dan pemahaman yang tinggi, serta kepedulian dan komitmen untuk menerapkan kebajikan dalam kehidupan sehari-hari. (E.Muliyasa pada Manajemen Pendidikan Karakter: 2012) lebih lanjut E.Muliyasa mengemukakan dalam konteks pemikiran islam karakter berkaitan dengan iman dan ikhsan. Hal ini sejalan dengan ungkapan Aristoteles bahwa karakter erat kaitannya dengan " habit" atau kebiasaan yang terus menerus dipraktekkan dan di amalkan. Lebih lanjut masih dari E.Muliyasa mengemukakan Megawangi pencetus pendidikan karakter diindonesia telah menyusun sembilan pilar karakter mulia yang selayaknya di jadikan acuan dalam pendidikan karakter, baik di sekolah maupun di luar sekolah, yaitu sebagai berikut: 1) Cinta Allah dan kebenaran 2) Tanggung jawab,disiplin dan mandiri 3)Amanah 4) Hormat dan santun 5) Kasih sayang, peduli dan kerjasama 6) Percaya diri, kreatif, dan pantang menyerah 7) Adil dan berjiwa kepemimpinan 8) Baik dan rendah hati 9) Toleransi dan cinta damai.

Dalam persepektif islam pendidikan karakter secara teoritiks sebenarnya telah ada sejak islam diturunkan kedunia seiring dengan di utusnya nabi Muhammad SAW untuk memperbaiki atau menyempurnakan akhlak (karakter) manusia. Ajaran islam sendiri mengandung sistematika ajaran yang tidak hanya menekankan pada aspek keimanan. Ibadah dan mu'amalah, tetapi juga akhlak. Pengamalan ajaran islam secara utuh (kaffah) merupakan model karakter seseorang muslim, bahkan di personifikasikan dengan model karakter nabi Muhammad SAW, yang memiliki sifat Shiddiq, Tabligh, Amanah, Fthona (STAP).

Pendidikan karakter sebenarnya telah dilaksanakan jauh sebelum indonesia merdeka. Ki Hajar Dewantara sebagai pahlawan pendidikan nasional memiliki pandangan tentang karakter sebagai asas Taman Siswa 1922. Dalam asas Taman Siswa tersebut Dewantara ingin mendidik manusia Indonesia secara utuh (kaffah) yang hidup mandiri, efektif, efisien, produktif dan akuntabel (E.Muliyasa:2012). 


\section{Kajian Teori}

Moral berasal dari bahasa latin "Mores" kata jamak dari "Mos" yang artinya adat kebiasaan, kelakuan, tabiat, akhlak yang kemudian artinya berkembang menjadi kebiasaan dalam bertingkah laku baik. Moral menurut Shaffer berarti menjadi penilaian perilaku kita dalam masyarakat ataupun kelompok sosial, sehingga jika moral kita baik akan berdampak positif dan jika moral itu buruk maka akan berdampak pada diri kita serta tercemarnya nama baik dalam lingkup lingkungan sosial sekitar.

Perkembangan moral seseorang melewati 3 fase, yakni: 1) Fase premoral atau prekonvebsional, pada level ini sikap dan prilaku manusia banyak dilandasi oleh imvuls biologis dan social 2) Tingkat konvensional; perkembangan moral manusia pada tahap ini banyak didasari oleh sikap kritis kelompoknya 3) Autinomos; pada tahapan ini perkembangan moral manusia banyak dilandaskan pada pola fikirannya sendiri.

Pada dasarnya manusia memiliki kesamaan pola perkembangan moral, seperti awal kehidupannya manusia tidak memiliki konsep berkehidupan yang mencerminkan nilai moral. Sebab tanpa landasan pendidikan, manusia akan banyak dikendalikan oleh dorongan kebutuhan biologisnya belaka ketika hendak menentukan segala sesuatu. Dari semua pendapat ahli dapat ditarik kesimpulan, bahwa perkembangan moral adalah suatu perkembangan dalam prilaku, tabiat atau akhlak yang baik atau buruk yang didasari oleh nilai - nilai budaya tempat dimana kita tinggal dan melakukan interaksi sosial demi terwujudnya kehidupan yang damai.

Terkait dengan perkembangan moralitas, anak usia dini pada dasarnya masih sangat memerlukan bantuan dalam hal seperti pembentukan karakter (Formation of character), pembentukan kepribadian (Shping of personality), dan perkembangan sosial (Social development). Perkembangan moral anak banyak dipengaruhi oleh lingkungannya. Anak memperoleh nilai-nilai moral dari lingkungannya, orang tuanya terutama dari dia belajar untuk mengenal nilai-nilai dan berprilaku sesuai dengan nilai-nilai tersebut. Dalam mengembangkan moral anak peranan orang tua sangatlh penting terutama pada waktu anak masih kecil.

Menurut Syamsu Yusuf LN, ada beberapa sikap orang tua yang harus diperhatikan sehubungan dengan perkembangan moral anak diantaranya sebagai berikut: 1) Konsisten dalam mendidik anak, ayah dan ibu harus memiliki sikaf dan perlakukan yang sama dalam melarang atau membolehkan tingkah laku tertentu kepada anak 2) Sikap orang tua dalam keluarga, secara tidak langsung sikap orang tua kepada anak, sikap ayah terhadap ibu atau sebaliknya, dapat mempengaruhi moral anak yaitu melalui proses peniruan (imitasi), sikap orang tuanya yang keras (otoriter) cenderung melahirkan sikap disiplin semu pada anak, sedangkan sikap 
acuh tak acuh atau sikap masa bodoh, cenderung mengembangkan sikap kurang bertanggung jawab dan kuarang memperdulikan norma pada diri anak. Sikap yang sebaiknya dimiliki orang tua adalah sikap kasih sayang, keterbukaan, musyawarah (dialogis) dan konsintensi 3) Penghayatan dan pengamalan agama yang dianut, orang tua merupakan panutan (teladan) bagi anak termasuk disini panutan dalam mengamalkan ajaran agama 4) Sikap konsisten orang tua dalam menerapkan norma, orang tua yang tidak menghendaki anaknya berbohong, atau berprilaku tidak jujur, maka mereka harus menjauhkan dirinya dari prilaku berbohong atau tidak jujur.

\section{METODE}

Jenis penelitian yang digunakan adalah Classroom Action Research atau penelitian kelas (PTK) yang tujuannya memperbaiki atau meningkatkan praktek pembelajaran dikelas. Penelitian ini bertujuan menanamkan kemampuan moral anak melalui buku bergambar pilar karakter sopan santun pada kelompok bermain Kartini Beringin Lestari.

Mills (2000) mendefinisikan penelitian ini sebagai "sistematic inquiry" yang dilakukan oleh guru, kepala sekolah atau konselor sekolah untuk mengumpulkan informasi tentang berbagai praktek yang dilakukannya. Informasi ini kemudian digunakan untuk meningkatkan persepsi serta mengembangkan "reflectif practice" yang berdampak positif dalam berbagai praktek persekolahan, termasuk memperbaiki hasil belajar siswa. Penelitian tindakan kelas juga merupakan penelitian yang dilakukan guru di dalam kelasnya sendiri refleksi diri dengan tujuan untuk memperbaiki kinerjanya sebagai guru, sehingga hasil belajar siswa meningkat.

1. Perencanaan. a) Rencana pelaksanaan pembelajaran harian (RPPH) b) Merancang pertanyaan yang sesuai dengan tema dan bahasan yang ingin dicapai c) Menyiapkan bahan pembelajaran sesuai dengan buku pilar d) Menyiapkan lembar observasi guru mengajar dan lembar observasi kemampuan Moral anak.

2. Pelaksanaan. a) Pembukaan b) kegiatan inti c) istirahat d) penutup

3. Tindakan Siklus. Pada tahap ini peneliti bersama guru mendesain pembelajaran tentang buku pilar karakter. Selama pembelajaran berlangsung peneliti dalam mengajar menggunakan RPPHyang telah disusun dengan pertimbangan dari guru kelas. Sedangkan guru kelas sebagai pengamat dimana lembar observasi sudah di siapkan oleh peneliti.

4. Observasi. a) Dapat menyimak pembahasan tentang buku pilar karakter b) Mampu memahami makna yang terkandung dalam buku pilar karakter c) Melakukan kegiatan pembelajaran tentang buku pilar karakter d) Dapat bertanya kembali tentang pembelajaran buku pilar karakter tersebut. 
5. Refleksi. Berdasarkan hasil refleksi peneliti melakukan penelitian didalam dan diluar kelas dengan melakukan evaluasi proses tindakan, menganalisis hambatan yang ditemui dan memikirkan pemecahan dan tujuannya. Masih ditemukan adanya kelemahan kelemahan yang akan di perbaiki pada siklus II.

6. Tindakan pada siklus II dilakukan berdasarkan perencanaan dan perbaikan dari hasil refleksi siklus sebelumnya, kemudian dilakukan refleksi untuk melihat sejauh mana perubahan yang terjadi melalui tindakan ke II.

\section{HASIL DAN PEMBAHASAN}

\section{Pra Tindakan}

Sebelum melakukan penelitian, terlebih dahulu dilaksanakan observasi pra tindakan untuk mengukur seberapa tingkat kemampuan anak didik KB Kartini. Selain itu observasi pra tindakan dilakukan untuk mencari titik masalah, solusi yang akan digunakan serta metode dan media yang akan diterapkan. Hasil pra tindakan ini juga sebagai acuan berapa persen peningkatan yang ingin dicapai setelah diadakan tindakan. Observasi pra tindakan ini di laksanakan hari Senin tanggal 11 Juli 2020. Dari observasi pra tindakan yang dilakukan menunjukkan hasil kegiatan belajar menanamkan moral sejak dini melalui buku bergambar pilar karakter sopan santun di kategorikan mulai berkembang 6 orang anak (28,57\%) yang dikategorikan mulai berkembang, dan 14 orang anak (0,7\%) yang dikategorikan belum berkembang.

Dari data tersebut dapat diambil rata-rata kemampuan penanaman moral karakter keseluruhannya sebesar 44\%. Berdasarkan hasil tersebut peneliti bersama kolaborator sepakat penelitian berhasil atau dapat dihentikan apabila rata-rata tingkat kemampuan pilar karakter sudah mencapai angka 65-75\%.

\section{Siklus I}

a. Perencanaan. Rencana Tindakan Siklus I antara lain: 1) Menentukan hari pelaksanaan siklus I, 2) Membuat rencana pelaksana pembelajaran 3) Menata ruang kelas 4) Mempersiapkan sarana dan media pembelajaran buku pilar karakter 5) Mempersiapkan lembar observasi yang digunakan pada saat pembelajaran.

b. Pelaksanaan Tindakan. Siklus I sebanyak 3 kali pertemuan yaitu pada tanggal 11,13 dan 15 Juli 2020. Kegiatan meliputi: 1) Membuka dengan doa dan salam 2) Memberikan pertanyaan seputar pilar 3) Menjelaskan isi pilar karakter 4) Memberikan penjelasan tentang buku pilar karakter sopan santun pada anak. 
c. Pengamatan dilakukan oleh guru sedangkan peneliti sebagai pelaksana pembelajaran. Pengamatan dilakukan selama kegiatan pembelajaran berlangsung dengan menggunakan lembar observasi yang sudah disiapkan oleh peneliti. Lembar observasi digunakan untuk mengetahui jalannya pembelajaran buku pilar karakter.

d. Refleksi Siklus I, peneliti mengumpulkan dan mengidentifikasi data yang telah di peroleh, yaitu mengikuti lembar observasi dan wawancara serta catatan dari guru. Kemudian peneliti melakukan refleksi. Pelaksanaan refleksi dilakukan antara peneliti dengan guru yang bersangkutan. Diskusi dilakukan dengan cara melakukan penilaian terhadap proses selama pembelajaran berlangsung. Masalah yang muncul dan berkaitan dengan hal - hal yang dilakukan setelah melakukan refleksi kemudian peneliti membuat rencana untuk siklus selanjutnya.

Berdasarkan hasil pengamatan kegiatan siklus 1, telah terjadi peningkatan pembelajaran pilar karakter. Hal itu dapat dilihat dari ketiga aspek yang diamati terjadi peningkatan. Namun hasil peningkatan tersebut belum memenuhi kriteria yang peneliti harapkan, belum mencapai ketuntasan minimal. Menurut pengamatan peneliti hasil kurang maksimal karena strategi pembelajaran klasikal, sehingga anak didik dalam mengamati gambar buku pilar karakter yang dijelaskan menjadi kurang fokus. Sebagian anak masih berbicara dengan teman sebelah atau bercanda dengan temannya. Penjelasan buku pilar 3 kali juga kurang maksimal. Untuk itu peneliti merencanakan mengubah strategi pembelajaran dari klasikal menjadi kelompok, dan menambah bercerita tentang buku pilar karakter sopan santun menjadi 4 kali bercerita.

\section{Siklus II}

a. Perencanaan. Rencana tindakan siklus I antara lain, 1) Menentukan hari pelaksanaan siklus II, 2) Membuat rencana pelaksanaan pembelajaran harian (RPPH) materi pilar karakter sopan santun 3) Menata ruang kelas 4) Membagi anak didik menjadi dua kelompok, masing - masing kelompok 10 anak, 5) Mempersiapkan sarana dan media pembelajaran buku pilar karakter 6) Mempersiapkan lembar observasi yang akan digunakan pembelajaran.

b. Pelaksanaan. Tindakan siklus II sebanyak tiga kali yaitu pada tanggal 18,20 dan 22 Juli 2020. Pelaksanaan tindakan siklus II meliputi, 1) Membuka kegiatan dengan doa 2) Memulai pembelajaran dengan pertanyaan buku pilar sopan santun dan apresiasi anak didik terhadap pilar siklus 1,3) Membuka buku pilar karakter sopan santun 4) Memberikan penjelasan tentang anak 
yang sopan santun 5) Anak menirukan bagaimana cara anak yang sopan santun 6) Kegiatan tersebut diulang sampai 4 kali.

c. Pengamatan dilakukan oleh guru sedangkan peneliti sebagai pelaksana pembelajaran. Pengamatan dilakukan selama kegiatan pembelajaran berlangsung dengan menggunakan lembar observasi yang sudah disiapkan oleh peneliti. Lembar observasi digunakan untuk mengetahui jalannya pembelajaran buku pilar karakter sopan santun.

d. Refleksi. Pada tahap ini peneliti mengumpulkan dan mengindentifikasi data yang telah diperoleh, yaitu meliputi lembar observasi dan wawancara serta catatan dari guru. Kemudian peneliti dengan guru yang bersangkutan. Diskusi dilakukan untuk mengevaluasi hasil yang telah dilakukan yaitu dengan cara melakukan penilaian terhadap proses selama pembelajaran berlangsung. Masalah yang muncul dan berkaitan dengan hal - hal yang dilakukan setelah melakukan refleksi kemudian peneliti membuat rencana untuk siklus selanjutnya.

Berdasarkan hasil pengamatan kegiatan siklus II, telah terjadi peningkatan kemampuan tentang pilar karakter sopan santun. Hal itu dapat dilihat dari ketiga aspek yang diamati terjadi peningkatan. Namun hasil peningkatan tersebut sudah memenuhi kriteria yang peneliti harapkan. Kriteria penilaian kemampuan tentang pilar karakter sopan santun sudah mencapai indikator yang ditentukan yakni antara 65\% $75 \%$ bahkan sudah melebihi kriteria. Berdasarkan refleksi diatas indikator keberhasilan sudah tercapai sehingga siklus dinyatakan berhenti.

Peningkatan kemampuan menanamkan moral sejak dini melalui buku bergambar pilar karakter sopan santun pada KB Kartini dapat dilihat dalam tabel berikut ini:

\begin{tabular}{|c|c|c|c|}
\hline Tindakan & Pra Tindakan & Siklus I & Siklus II \\
\hline Jumlah Skor & 102 & 187 & 284 \\
\hline Persentase & $31,87 \%$ & $58,43 \%$ & $88,75 \%$ \\
\hline
\end{tabular}

Berdasarkan tabel diatas dapat beberapa hal: siklus I, berkembang sesuai harapan 4 anak (19,05\%), dan mulai berkembang 16 anak (0,8\%). Pada siklus II, berkembang sangat baik 10 anak (0,5\%) berkembang sesuai harapan 5 anak (0,25\%), mulai berkembang 5 anak $(0,25 \%)$. Dari data terseebut dapat diambil kesimpulan bahwa dengan media buku pilar karakter terbukti mampu meningkatkan sopan santun pada anak didik KB Kartini Beringin Lestari.

Cara penerapan yang digunakan pada siklus I adalah dengan cara klasikal penerapan pada siklus II dengan berkelompok dari dua 
cara tersebut dapat dilihat bahwa cara berkelompok lebih efektif daripada cara klasikal. Pada cara berkelompok anak - anak menjadi lebih fokus memperhatikan media buku pilar karakter sopan santun, dan berarti lebuh meningkatkan daya serap anak. Berdasarkan penjelasan diatas dapat ditarik kesimpulan bahwa cara penerapan yang paling tepat untuk menerapkan dengan media buku pilar karakter pada KB Kartini Beringin Lestari dengan cara membentuk kelompok kecil.

\section{SIMPULAN}

Dari rangkaian penelitian yang telah dilakukan, mulai dari tindakan pra siklus, siklus I sampai siklus II banyak temuan yang peneliti kumpulkan. Setelah dilakukan observasi dan penilaian menggunakan indikator yang telah peneliti buat dapat ditarik kesimpulan bahwa kemampuan moral anak kelompok KB Kartini mengalami peningkatan signifikan. Mulai kemampuan anak menyimak kegiatan bercerita debgan baik dapat melakukan prilaku sopan santun, dapat memasangkan prilaku sopan santun yang benar hingga anak juga dapat menyebutkan prilaku yang salah atau tidak sopan. Kesimpulan ini dibuktikan dengan persentase perkembangan kemampuan moral anak yang hanya $31,87 \%$ pada pra siklus, berkembang menjadi $88,75 \%$ setelah dilakukan tindakan siklus II. Temuan diatas membuktikan bahwa hipotesis awal peneliti yang menyebutkan bahwa dengan buku bergambar pilar karakter sopan santun dapat menanamkan moral pada anak di KB Kartini terbukti benar.

\section{DAFTAR PUSTAKA}

Abdurrahman,M,Sujjadi S,(1994).Pendidikan luar biasa umum. Jakarta: Depdikbud Dirjen Dikti PPTA

Ali, Muhammad. (2008). Pengembangan kurikulum di Sekolah. Bandung; Sinar Baru Algensindo

Andi Hakim Nasoetion. (1982). Anak Berbakat dan Kemungkinan menemukannya di Indonesia. Jakarta : C.V Rjawali

Anitah, Sri. (2008). Strategi Pembelajaran untuk anak berbakat. Jakarta: Universitas Terbuka.

Clark, Barbara. (1983). Growing Up Gifted. Columbus Ohio; Charle s E. Merril Publishing Company,

Danuatmaja,B. (2003. Terapi Anak Autis di Rumah.Jakarta: Puspa Suara

Delphie, Bandi. (2006). Pembelajaran Anak Berkebutuhan Khusus. Bandung; PT Refika Aditama

Departemen pendidikan dan kebudayaan. (1994). pengembangan sekolah Unggul. Jakarta : Depdikbud

Ellah Siti Chalidah. (2005). Model pelayanan pendidikan anak autis.Jakarta: Raja Gravindo pers

Erianawati. (2005). Penggunaan Media Visual untuk ABK, (online)

Hamalik, Oemar. (2007). Manjemen Pengembangan Kurikulum, Bandung: PT Remaja Rosdakarya 
Hernawati, Tati. Definisi, Penyebab, Dan Jenis-Jenis Kesulitan Belajar: Diakses dari http://file.upi.edu, pada tanggal 13 Oktober 2012.

Hidayat, dkk. (2006). Bimbingan Anak Berkebutuhan Khusus. Bandung: UPI

Imandala, lim. (2008). Penanganan Anak Berkesulitan Belajar: Diakses dari http://pendidikankhusus.wordpress.com, pada tanggal 15 Oktober 2012. Jakarta: Universitas Terbuka.

Kartadinata, Sunaryo. (1996). Psikologi Anak Luar Biasa. Surabaya : Dikti

Kembara Maulia D .(2007). Homeschooling, Bandung: Progressio. 